\title{
Chemical and Biological Properties of Apple Orchard Soils under Natural, Organic, Hybrid, and Conventional Farming Methods
}

\author{
Takamitsu Kai1 ${ }^{*}$, Motoki Kubo² \\ ${ }^{1}$ Kurokawa Field Science Center, Meiji University, Kawasaki, Japan \\ ${ }^{2}$ Department of Biotechnology, Faculty of Life Sciences, Ritsumeikan University, Kusatsu, Japan \\ Email: ^kai_takamitsu@meiji.ac.jp
}

How to cite this paper: Kai, T. and Kubo, M. (2020) Chemical and Biological Properties of Apple Orchard Soils under Natural, Organic, Hybrid, and Conventional Farming Methods. Journal of Agricultural Chemistry and Environment, 9, 134-146. https://doi.org/10.4236/jacen.2020.93012

Received: June 18, 2020

Accepted: August 11, 2020

Published: August 14, 2020

Copyright $\odot 2020$ by author(s) and Scientific Research Publishing Inc. This work is licensed under the Creative Commons Attribution International License (CC BY 4.0).

http://creativecommons.org/licenses/by/4.0/

(c) (i) Open Access

\begin{abstract}
Apples in Japan are generally cultivated under management systems that use chemical fertilizers and synthetic chemical pesticides. However, the continuous use of these fertilizers and pesticides damages the soil environment and reduces the number of soil microorganisms. In this study, we compared the chemical and biological properties of 12 soils from apple orchards in Aomori and Nagano Prefectures under four types of management systems, namely, natural conditions, with no cultivation, fertilizers, or pesticides; organic farming methods, using organic materials and pesticides approved by the Japanese Agricultural Standard organic certification system; hybrid farming methods, using a mix of organic and chemical fertilizers; and conventional farming, using chemical fertilizers and pesticides. Soil total carbon (TC), total nitrogen (TN), total phosphorus (TP), nitrate-nitrogen $\left(\mathrm{NO}_{3}^{-}\right)$, and available phosphoric acid (SP) contents were generally found to be the highest where organic farming methods were used. Similarly, bacterial biomass, nitrification $(\mathrm{N})$ circulation activity, ammonia $\left(\mathrm{NH}_{4}^{+}\right)$oxidation activity, nitrite $\left(\mathrm{NO}_{2}^{-}\right)$oxidation activity, and phosphoric $(\mathrm{P})$ circulation activity were the highest under organic farming, especially in comparison with conventional farming. This study indicated that the differences in apple sugar content, acidity, and sugar/acidity ratio between different orchard management systems were due to different soil conditions, and soil conditions under organic farming management system in apple cultivation increased bacterial biomass while enhancing $\mathrm{N}$ and $\mathrm{P}$ circulation activity and high TC. On the other hand, the soil of conventional farming has the lowest total number of bacterial biomass and lowest material cycle such as $\mathrm{N}$ and $\mathrm{P}$ circulation activity. Analysis of the chemical and biological properties of these orchard soils
\end{abstract}


indicated that soil conditions under organic farming management are the most suitable for increasing microbial numbers and enhancing $\mathrm{N}$ and $\mathrm{P}$ circulation activity.

\section{Keywords}

Organic Farming, Soil Microorganisms, Soil Fertility, Agricultural

Environment, Environmental Conservation

\section{Introduction}

Apples (Malus domestica Borkh.) are believed to have originated in the region between the northern Caucasus and the Tianshan mountains in west and central Asia [1]. Currently, there are about 15,000 apple varieties worldwide, mainly in the subtropical, temperate, and subarctic regions, including those in China, Korea, North America, and Australia, and about 2000 in Japan [2]. The development of new varieties and discoveries of changes in branching architecture have allowed apples to become one of the most widely cultivated and productive fruit crops in the world [3]. The Fuji apple variety was developed in Fujisaki City, Aomori Prefecture, in 1962, and it is currently the most commonly produced Japanese apple variety, with large volumes of export to other countries. Cool climate regions with average annual temperatures of $6^{\circ} \mathrm{C}-14^{\circ} \mathrm{C}$, low annual rainfall, and wide temperature differences between day and night are best suited for apple cultivation [4]. Therefore, Japanese apples are mainly cultivated in Aomori, Nagano, Iwate, Yamagata, and Fukushima Prefectures, among which Aomori and Nagano Prefectures account for approximately $77 \%$ of the total national production [5]. The overall mean annual apple yield in Japan is $21.2 \mathrm{t} \cdot \mathrm{ha}^{-1}$ per year, which is lower than the yields obtained in other developed countries, e.g., $77.9 \mathrm{t} \cdot \mathrm{ha}^{-1}$ per year in Australia, $47.4 \mathrm{t} \cdot \mathrm{ha}^{-1}$ per year in New Zealand, and $31.9 \mathrm{t} \cdot \mathrm{ha}^{-1}$ per year in the United States [6]. Poor soil fertility seems to be one of the most important reasons for the prevalent low productivity of this highly important fruit crop in Japan [2].

Most of the apple production in Japan relies on the use of chemical fertilizers and synthetic pesticides [7]. Chemical fertilizers have made it possible to effectively supply nutrients to the soil because they are soluble in water and have an immediate effect [7], thereby reducing the labor needed for fertilizer application and greatly increasing the yield per unit area. Therefore, the use of chemical fertilizers and synthetic pesticides has increased apple productivity. However, the continuous use of these chemical fertilizers and synthetic chemical pesticides demonstrably deteriorates the soil environment and reduces soil microorganism function and diversity. Although organic production systems might reduce soil damage, previous studies suggest that organic farming systems typically show $20 \%$ to $30 \%$ lower productivity than conventional systems that make heavy use of chemical fertilizers and pesticides [8] [9]. 
Although, as stated before, poor soil fertility is thought to be one of the major reasons for the lower apple productivity of apple orchards in several prefectures, information on the relationship between soil properties and apple productivity is scarce [10] [11] [12].

Previously, we reported that organic fertilizer-based systems can effectively support stable and high crop productivity by maintaining suitable bacterial biomass levels, $\mathrm{N}$ circulation activity, and $\mathrm{P}$ circulation activity by controlling TC and TN contents and the C/N ratio in the soil [13]. Excessive levels of TC, TN, TP, and total potassium (TK) in Japanese orchards that use conventional chemical fertilizer management systems can reduce yields [14]. In addition, apple orchards are relatively rich in TC, TN, TP, and TK, compared to annual croplands such as paddy fields and uplands [15]. Therefore, to assess the characteristics of organic soil condition under four agricultural methods, we compared the chemical and biological properties of soils under natural farming, organic farming, hybrid agricultural methods using both organic and chemical fertilizers, and conventional chemical fertilizer methods.

\section{Materials and Methods}

\subsection{Study Sites}

In 2019, we selected 12 differentially productive apple orchards under differing fertilizer, pesticide, and tillage management systems in Aomori and Nagano Prefectures. Experimental treatments are shown in Table 1. The soils in these orchards are volcanic ash soils. Natural farming involves management systems that do not use fertilizers, pesticides, or tillage; apple organic farming uses only

Table 1. Experimental treatments.

\begin{tabular}{|c|c|c|c|c|c|c|}
\hline \multicolumn{3}{|c|}{ Experiment treatments } & \multirow{2}{*}{$\begin{array}{c}\text { Fertilizer } \\
\text { None }\end{array}$} & \multirow{2}{*}{$\begin{array}{c}\text { Pesticide } \\
\text { None }\end{array}$} & \multirow{2}{*}{$\begin{array}{c}\text { plowing } \\
\text { None }\end{array}$} & \multirow{2}{*}{$\begin{array}{c}\begin{array}{c}\text { yield } \\
\left(\mathrm{t} \cdot \mathrm{ha}^{-1}\right)\end{array} \\
5\end{array}$} \\
\hline 1 & Natural farming & Aomori & & & & \\
\hline 2 & Natural farming & Aomori & None & None & None & 7 \\
\hline 3 & Natural farming & Nagano & None & None & None & 10 \\
\hline 4 & Organic farming & Aomori & Chicken dung compost & Pesticides approved by JAS organic certification & Yes & 30 \\
\hline 5 & Organic farming & Aomori & $\begin{array}{l}\text { Chicken dung, rice bran, } \\
\text { rapeseed meal, fish cake }\end{array}$ & Pesticides approved by JAS organic certification & Yes & 45 \\
\hline 6 & Organic farming & Nagano & Cow dung compost & Pesticides approved by JAS organic certification & Yes & 20 \\
\hline 7 & Hybrid farming & Aomori & Organic and chemical fertilizers & Reduction of synthetic chemical pesticides & Yes & 30 \\
\hline 8 & Hybrid farming & Nagano & Organic and chemical fertilizers & Reduction of synthetic chemical pesticides & Yes & 30 \\
\hline 9 & Hybrid farming & Nagano & Organic and chemical fertilizers & Reduction of synthetic chemical pesticides & Yes & 30 \\
\hline 10 & Conventional farming & Aomori & Chemical fertilizers & Synthetic chemical pesticides & Yes & 30 \\
\hline 11 & Conventional farming & Aomori & Chemical fertilizers & Synthetic chemical pesticides & Yes & 40 \\
\hline 12 & Conventional farming & Nagano & Chemical fertilizers & Synthetic chemical pesticides & Yes & 30 \\
\hline
\end{tabular}


compost and organic materials as fertilizers, and pesticides as prescribed by the Japanese Agricultural Standard system are sprayed 1 - 2 times each year. Hybrid apple farming uses a combination of chemical and organic fertilizers, plus synthetic chemical pesticides sprayed 5 - 7 times each year, and conventional chemical methods of apple cultivation use chemical fertilizers and synthetic pesticides that are sprayed 11 - 14 times each year. As many pests infest apple orchards, a total of 40 or more synthetic chemical pesticides are sprayed every 10 days over the entire growing season. Synthetic chemical pesticides, irrigation, and cultivation operations are applied as per the recommendations for Aomori and Nagano Prefectures by the Japanese Government [16]. For example, in Aomori Prefecture, fertilization rates of $0.15 \mathrm{t} \cdot \mathrm{ha}^{-1}$ of N, $0.05 \mathrm{t} \cdot \mathrm{ha}^{-1}$ of $\mathrm{P}_{2} \mathrm{O}_{5}$, and $0.05 \mathrm{t} \cdot \mathrm{ha}^{-1}$ of $\mathrm{K}_{2} \mathrm{O}$ are recommended. In turn, recommended fertilization rates in Nagano Prefecture are $0.12-0.20,0.04-0.06$, and $0.10-0.14 \mathrm{t} \cdot \mathrm{ha}^{-1}$ of $\mathrm{N}, \mathrm{P}_{2} \mathrm{O}_{5}$, and $\mathrm{K}_{2} \mathrm{O}$, respectively. The experiment treatments have been under the same farming methods for five years. All 12 selected orchards contain 10 - 20-year-old Fuji/Marubakaidou (Malus prunifolia Borkh. Var. ringo Asami) trees. The climate in Aomori and Nagano Prefecture is humid temperate; July is the warmest month, while January is the coolest.

\subsection{Fruit Sugar, Acidity, and Sugar/Acidity Ratio}

Fruit sugar content and acidity were analyzed using a pocket sugar-acidity meter (PAL-BX/ACID5; Atago, Tokyo, Japan). Sugar content was determined by dripping undiluted apple juice onto the sensor of the pocket sugar-acidity meter; each apple juice sample was measured thrice, and the average was calculated. Acidity was measured by diluting $1 \mathrm{~mL}$ of apple juice to $50 \mathrm{~mL}$ by gently stirring in purified water (100 rpm, $5 \mathrm{~min}$ ) and placing a drop of the diluted juice on the pocket sugar-acidity meter sensor. Again, each apple juice sample was measured thrice, and the average was calculated. The sugar/acid ratio was calculated as sugar content divided by acidity.

\subsection{Soil Chemical Properties}

Composite soil samples (top $15 \mathrm{~cm}$ layer, excluding the top $2-3 \mathrm{~cm}$ surface crust) were collected near the base of five randomly selected trees in each orchard. Soil sampling was performed in July when soil microorganisms were active [14]. The following chemical properties of the composite soil samples were analyzed: TC, TN, $\mathrm{NH}_{4}^{+}, \mathrm{NO}_{3}^{-}, \mathrm{TP}, \mathrm{SP}, \mathrm{TK}$, and exchangeable potassium (SK). TC content was analyzed with a TOC analyzer (SSM-5000A; Shimadzu, Kyoto, Japan). $\mathrm{NH}_{4}^{+}$and $\mathrm{NO}_{3}^{-}$were analyzed by extracting the soil sample with $1 \mathrm{M} \mathrm{KCl}$, followed by the indophenol blue method and brucine methods [17]. A soil-water suspension $(1: 20, \mathrm{w} / \mathrm{v})$ was reciprocally shaken at $100 \mathrm{rpm}$ for $1 \mathrm{~h}$, and the extracts were analyzed using the molybdenum blue method [18] and atomic absorption spectrophotometry for quantitative determination of SP and SK, respectively. TN, TP, and TK contents were analyzed by digesting the soil samples 
in a Kjeldahl Therm digestion unit (Gerhardt, Königswinter, Germany) with $\mathrm{H}_{2} \mathrm{SO}_{4}$ and $\mathrm{H}_{2} \mathrm{O}_{2} ; \mathrm{NH}_{4}^{+}-\mathrm{N}, \mathrm{SP}$, and $\mathrm{SK}$ contents in the digest were determined. The $\mathrm{pH}$ of the soil-water suspension $(1: 2.5, \mathrm{w} / \mathrm{v})$ was analyzed using a $\mathrm{pH}$ meter (Model: LAQUA F-72; Horiba Scientific, Kyoto, Japan).

\subsection{Soil Biological Properties}

Nitrogenous organic substances, such as proteins, are decomposed in soil as follows: $\mathrm{NH}_{4}^{+} \rightarrow \mathrm{NO}_{2}^{-} \rightarrow \mathrm{NO}_{3}^{-}$, after protein $\rightarrow$ peptide $\rightarrow$ amino acid and low-molecular-weight molecules derived from amino acid decomposition are rendered by soil microorganisms. During these processes, $\mathrm{NH}_{4}^{+}$oxidation activity $\left(\mathrm{NH}_{4}^{+} \rightarrow \mathrm{NO}_{2}^{-}\right), \mathrm{NO}_{2}^{-}$oxidation activity $\left(\mathrm{NO}_{2}^{-} \rightarrow \mathrm{NO}_{3}^{-}\right)$, and bacterial biomass were determined. Bacterial biomass was determined by environmental DNA (eDNA) analysis, which allows an accurate and simple measurement by extracting microbial DNA from the soil. $\mathrm{NH}_{4}^{+}$oxidation activity, $\mathrm{NO}_{2}^{-}$oxidation activity, and the number of microorganisms were quantified with a triangular radar chart, and the ability of the soil to convert $\mathrm{N}$ in organic matter to $\mathrm{NO}_{3}^{-}$was evaluated as "N circulation activity" [19]. The larger the area of the triangle, the more active the nitrogen circulation in the soil, and vice versa. In addition, phytic acid (organic phosphate) must be broken down into phosphate before the plant can absorb phosphate (phytic acid-degrading activity). Therefore, the ability to convert phytic acid into organic phosphate was evaluated as "P circulation activity" [19].

Different soils were assigned a certain score: soils in which all phytic acid changed to phosphoric acid without chemisorption with minerals were given a score of 100 points, while soils in which phosphoric acid was not produced at all were assigned a score of 0 points. However, a $\mathrm{P}$ circulation activity score of 100 points indicated a low mineral content. Therefore, soils with a moderate mineral content and abundant microorganisms (due to phosphoric acid being supplied) were assigned a score of 40 - 60 points.

The following biological properties were analyzed: total bacterial biomass, $\mathrm{NH}_{4}^{+}$ oxidation activity, $\mathrm{NO}_{2}^{-}$oxidation activity, $\mathrm{N}$ circulation activity, and $\mathrm{P}$ circulation activity. Total bacterial biomass was estimated by quantifying eDNA using the slow-stirring method [20]. The $\mathrm{N}$ circulation activity was analyzed using $\mathrm{NH}_{4}^{+}$ and $\mathrm{NO}_{2}^{-}$oxidation activity values and total bacterial number, as described by Matsuno et al. (2013) [21] and Adhikari et al. (2014) [13]. P circulation activity was determined by analyzing the rate at which soluble $\mathrm{P}$ was released from phytic acid (a dominant form of organic P in soil) over a three-day incubation period [14] [15] [22].

\subsection{Statistical Analysis}

Data in tables and figures are means \pm SD analyzed using Bell Curve for Excel 2016 for Windows (Social Survey Research Information Co., Ltd., Tokyo, Japan). All data were analyzed using ANOVA followed by Fisher's least significant dif- 
ference test where appropriate. All statistical analyses were conducted at a significance level of $\alpha=0.05(P<0.05)$.

\section{Results}

\subsection{Comparison of Fruit Content and Acidity}

Sugar content, acidity, and sugar/acidity ratio of apple fruits grown under the four farming management strategies are summarized in Table 2. Sugar content was the highest in apples from organic orchards, although it did not significantly differ from the other treatments. In contrast, acidity was highest in apples from hybrid orchards.

Furthermore, sugar/acidity ratios were significantly higher in the natural and organic orchards than under hybrid or conventional management. Fuji apples are judged most delicious when their sugar content is $\geq 14 \%$, acidity is $0.4 \%$, and sugar/acid ratio is $30-40$ [23]. Apples from organic orchards showed a sugar content of $13.7 \%$, acidity of $0.4 \%$, and sugar/acidity ratio of 34.3 , implying that these apples were the closest to the established "delicious taste" requirements. Overall, our data suggested that the differences in apple sugar content, acidity, and sugar/acidity ratio between the different orchard management systems were attributed to differences in soil conditions.

\subsection{Comparison of Soil Chemical Properties}

Chemical properties of the orchard soils sampled in July under natural, organic, hybrid, and conventional management systems are shown in Table 3.

TC contents of the natural, organic, hybrid, and conventional system soils were 22,270 - 78,210, 31,290 - 143,700, 21,600 - 58,300, and 28,740 - 49,490 $\mathrm{mg} \cdot \mathrm{kg}^{-1}$, respectively. In turn, TN content ranges were 1340 - 3240, 2190 12,310, 690 - 2600, and $2030-3070 \mathrm{mg} \cdot \mathrm{kg}^{-1}$, respectively. TP contents were 1060 - 2500, $6820-24,280,3400-11,300$, and $1070-2360 \mathrm{mg} \cdot \mathrm{kg}^{-1}$, and TK contents ranges were $1820-8110,2590-5130,4700-14,500$, and $7050-8390 \mathrm{mg} \cdot \mathrm{kg}^{-1}$, respectively. Furthermore, $\mathrm{NO}_{3}^{-}-\mathrm{N}$ content values were $6-18,17-64,0-9$, and 6 - $9 \mathrm{mg} \cdot \mathrm{kg}^{-1}, \mathrm{NH}_{4}^{+}-\mathrm{N}$ content values were $0-5,1-3,0-2$, and $3-25 \mathrm{mg} \cdot \mathrm{kg}^{-1}$. while SP contents were 46- 495, $2196-13,017,10-81$, and $66-1234 \mathrm{mg} \cdot \mathrm{kg}^{-1}$,

Table 2. Sugar content, acidity, and sugar/acidity ratio of apple fruit.

\begin{tabular}{cccc}
\hline Experiment treatments & Sugar (Brix \%) & Acidity (\%) & Sugar acidity ratio \\
\hline Natural farming & $12.7 \pm 1.50 \mathrm{a}$ & $0.30 \pm 0.15 \mathrm{~b}$ & $42.3 \pm 19.1 \mathrm{a}$ \\
Organic farming & $13.7 \pm 2.31 \mathrm{a}$ & $0.40 \pm 0.31 \mathrm{~b}$ & $34.3 \pm 19.1 \mathrm{a}$ \\
Hybrid farming & $12.2 \pm 1.33 \mathrm{a}$ & $1.02 \pm 0.72 \mathrm{a}$ & $12.0 \pm 21.1 \mathrm{~b}$ \\
Conventional farming & $12.4 \pm 0.83 \mathrm{a}$ & $0.68 \pm 0.20 \mathrm{ab}$ & $18.2 \pm 7.79 \mathrm{~b}$ \\
\hline
\end{tabular}

${ }^{\mathrm{z}}$ Mean \pm standard deviation of a sample (sugar content, acidity, sugar/acidity ratio; $\mathrm{n}=5-16$ ). ${ }^{\mathrm{y}} \mathrm{Different}$ letters within columns are significantly different at the $\mathrm{P}<0.05$ level, according to the Tukey-Kramer method. 
Table 3. Soil chemical properties.

\begin{tabular}{|c|c|c|c|c|c|c|c|c|c|c|c|c|}
\hline No & $\begin{array}{l}\text { Experimental } \\
\text { treatments }\end{array}$ & $\begin{array}{c}\mathrm{TC} \\
\left(\mathrm{mg} \cdot \mathrm{kg}^{-1}\right)\end{array}$ & $\begin{array}{c}\mathrm{TN} \\
\left(\mathrm{mg} \cdot \mathrm{kg}^{-1}\right)\end{array}$ & $\begin{array}{c}\mathrm{TP} \\
\left(\mathrm{mg} \cdot \mathrm{kg}^{-1}\right)\end{array}$ & $\begin{array}{c}\mathrm{TK} \\
\left(\mathrm{mg} \cdot \mathrm{kg}^{-1}\right)\end{array}$ & $\begin{array}{l}\mathrm{C} / \mathrm{N} \\
\text { ratio }\end{array}$ & $\begin{array}{c}\mathrm{NO}_{3}^{-}-\mathrm{N} \\
\left(\mathrm{mg} \cdot \mathrm{kg}^{-1}\right)\end{array}$ & $\begin{array}{c}\mathrm{NH}_{4}^{+}-\mathrm{N} \\
\left(\mathrm{mg} \cdot \mathrm{kg}^{-1}\right)\end{array}$ & $\begin{array}{c}\text { SP } \\
\left(\mathrm{mg} \cdot \mathrm{kg}^{-1}\right)\end{array}$ & $\begin{array}{c}\mathrm{SK} \\
\left(\mathrm{mg} \cdot \mathrm{kg}^{-1}\right)\end{array}$ & $\mathrm{pH}$ & $\begin{array}{c}\mathrm{EC} \\
\left(\mathrm{mS} \cdot \mathrm{cm}^{-1}\right)\end{array}$ \\
\hline 1 & Natural farming & 22,270 & 1340 & 1060 & 6830 & 16.6 & 6 & 5 & 327 & 2120 & 6.2 & 0.31 \\
\hline 2 & Natural farming & 26,050 & 1440 & 1240 & 1820 & 18.1 & 8 & 0 & 46 & 87 & 6.1 & 0.12 \\
\hline 3 & Natural farming & 78,210 & 3240 & 2500 & 8110 & 24.1 & 18 & 2 & 495 & 1890 & 6.7 & 0.22 \\
\hline 4 & Organic farming & 143,700 & 12,310 & 24,280 & 2590 & 11.7 & 64 & 3 & 13,017 & 1436 & 7.1 & 1.09 \\
\hline 5 & Organic farming & 31,290 & 2190 & 7340 & 5130 & 14.3 & 17 & 1 & 2196 & 1457 & 7.4 & 0.29 \\
\hline 6 & Organic farming & 55,460 & 3300 & 6820 & 4530 & 16.8 & 37 & 1 & 2300 & 1116 & 6.9 & 0.38 \\
\hline 7 & Hybrid farming & 21,600 & 690 & 3400 & 10,800 & 31.3 & 0 & 2 & 10 & 29 & 6.5 & 0.10 \\
\hline 8 & Hybrid farming & 58,300 & 2600 & 11,300 & 14,500 & 22.4 & 9 & 1 & 81 & 156 & 7.3 & 0.10 \\
\hline 9 & Hybrid farming & 42,300 & 1600 & 3400 & 4700 & 26.4 & 0 & 0 & 52 & 62 & 6.8 & 0.10 \\
\hline 10 & Conventional farming & 28,740 & 2030 & 1070 & 7050 & 14.2 & 6 & 25 & 66 & 2100 & 5.4 & 0.38 \\
\hline 11 & Conventional farming & 49,490 & 3070 & 2360 & 8390 & 16.1 & 7 & 20 & 1234 & 1075 & 6.4 & 0.36 \\
\hline 12 & Conventional farming & 41,080 & 2500 & 1310 & 7060 & 16.4 & 9 & 3 & 914 & 1502 & 7.0 & 0.46 \\
\hline
\end{tabular}

respectively. SK contents were 87 - 2120, 1116 - 1457, 29 - 156, and 1075 - 2100 $\mathrm{mg} \cdot \mathrm{kg}^{-1}$, respectively. Overall, $\mathrm{TC}, \mathrm{TN}, \mathrm{TP}, \mathrm{NO}_{3}^{-}-\mathrm{N}$, and SP contents were the highest in organic farming orchards. The soil in one of the organic orchards (No. 4) showed excess TC, TN, and TP, while the highest TK content was recorded in soils under hybrid management. The $\mathrm{C} / \mathrm{N}$ ratios in natural, organic, hybrid, and conventional orchard soils were 16.6 - 24.1, 11.7 - 16.8, 22.4 - 31.3, and 14.2 - 16.4, respectively; thus, the highest $\mathrm{C} / \mathrm{N}$ ratio was registered in orchards under hybrid farming. However, as soil inorganic nitrogen is readily used by microorganisms while decomposing organic matter, in such high $\mathrm{C} / \mathrm{N}$ ratio soils, $\mathrm{N}$ might soon become deficient and microorganisms might become $\mathrm{N}$ starved, thereby inhibiting apple growth.

\subsection{Comparison of Soil Biological Properties}

Biological properties of the soils sampled in July from the four farming management strategies are summarized in Table 4, and radar charts of average $\mathrm{N}$ circulation activity from the natural, organic, hybrid, and conventional farming systems are shown in Figure 1. Average P circulation activity from the natural, organic, hybrid, and conventional farming systems are shown in Figure 2.

Ranges of bacterial biomass under these four farming methods were 2.6 - 10.0, 4.5 - 12.4, 4.8 - 7.2, and $(1.8-5.1) \times 10^{8}$ cells $\mathrm{g}^{-1}$, respectively, while $\mathrm{N}$ circulation activities were $22-75,39-100,30-48$, and $1-10$ points. In turn, $\mathrm{NH}_{4}^{+}$oxidation activities were $15-82,75-100,23-40$, and 4 - 10, respectively, while $\mathrm{NO}_{2}^{-}$ oxidation activities were 52 - 99, 40 - 100, 36 - 90, and 0 - 51. Moreover, P circulation activities were $10-23,16-40,1-32$, and $0-1$, respectively. These results indicated that bacterial biomass, $\mathrm{N}$ circulation activity, $\mathrm{NH}_{4}^{+}$oxidation activity, $\mathrm{NO}_{2}^{-}$oxidation activity, and $\mathrm{P}$ circulation were the highest in organic farming 
Bacterial biomass

$\mathrm{NO}_{2}$ oxidation activity

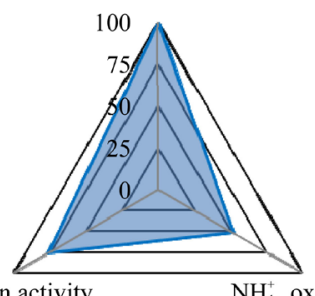

Average $\mathrm{N}$ circulation activity 48.0 point

(a)

Bacterial biomass

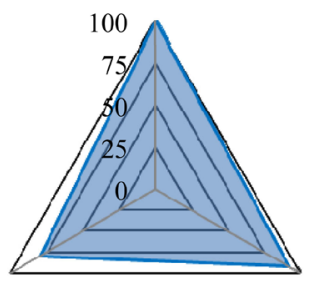

$\mathrm{NO}_{2}^{-}$oxidation activity $\quad \mathrm{NH}_{4}^{+}$oxidation activity

Average $\mathrm{N}$ circulation activity 79.3 point

(b)

Bacterial biomass

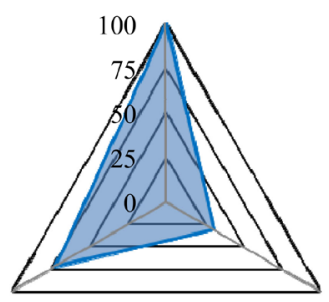

$\mathrm{NO}_{2}^{-}$oxidation activity

$\mathrm{NH}_{4}^{+}$oxidation activity

Average $\mathrm{N}$ circulation activity 39.6 point

(c)

Bacterial biomass

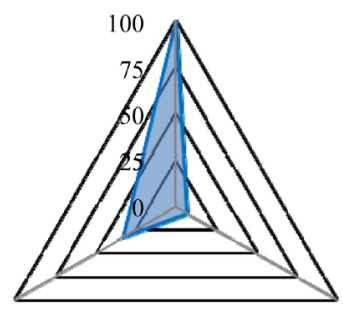

$\mathrm{NO}_{2}^{-}$oxidation activity

$\mathrm{NH}_{4}^{+}$oxidation activity

Average $\mathrm{N}$ circulation activity 6.0 point

(d)

Figure 1. Radar chart of $\mathrm{N}$ circulation activity using (a) natural; (b) organic; (c) hybrid; and (d) conventional farming methods. 


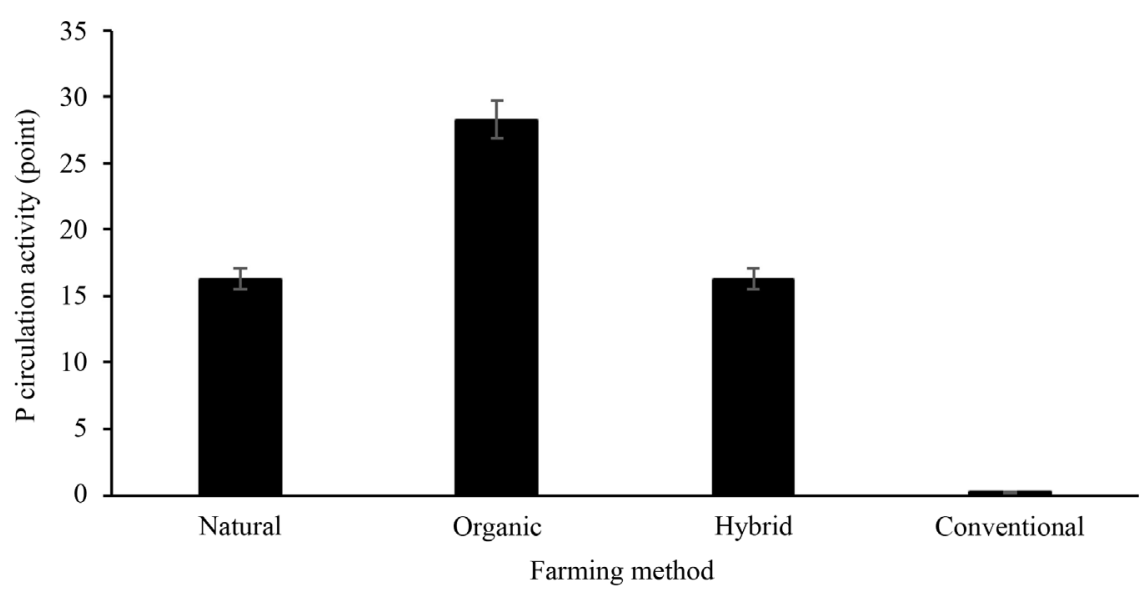

Figure 2. Average $\mathrm{P}$ circulation activity.

Table 4. Soil biological properties.

\begin{tabular}{ccccccc}
\hline No & $\begin{array}{c}\text { Experimental } \\
\text { treatments }\end{array}$ & $\begin{array}{c}\text { Bacterial } \\
\text { biomass } \\
\left(\times 10^{8} \text { cells } \mathrm{g}^{-1}\right)\end{array}$ & $\begin{array}{c}\mathrm{N} \\
\text { circulation } \\
\text { activity } \\
\text { (point) }\end{array}$ & $\begin{array}{c}\mathrm{NH}_{4}^{+} \\
\text {oxidation } \\
\text { activity } \\
\text { (point) }\end{array}$ & $\begin{array}{c}\mathrm{NO}_{2}^{-} \\
\text {oxidation } \\
\text { activity } \\
\text { (point) }\end{array}$ & $\begin{array}{c}\mathrm{P} \\
\text { circulation } \\
\text { activity } \\
\text { (point) }\end{array}$ \\
\hline 1 & Natural farming & 2.6 & 22 & 15 & 99 & 10 \\
2 & Natural farming & 10.0 & 47 & 58 & 52 & 16 \\
3 & Natural farming & 7.5 & 75 & 82 & 79 & 23 \\
4 & Organic farming & 7.6 & 100 & 100 & 100 & 40 \\
5 & Organic farming & 4.5 & 39 & 75 & 40 & 29 \\
6 & Organic farming & 12.4 & 99 & 100 & 99 & 16 \\
7 & Hybrid farming & 6.6 & 48 & 30 & 89 & 1 \\
8 & Hybrid farming & 7.2 & 30 & 40 & 36 & 16 \\
9 & Hybrid farming & 4.8 & 41 & 23 & 90 & 32 \\
10 & Conventional farming & 1.8 & 7 & 10 & 47 & 0 \\
11 & Conventional farming & 3.0 & 10 & 6 & 51 & 1 \\
12 & Conventional farming & 5.1 & 1 & 4 & 0 & 0 \\
\hline
\end{tabular}

orchards and the lowest in conventional orchards. Thus, apple orchard soils under organic farming methods showed increased bacterial biomass and enhanced $\mathrm{N}$ and $\mathrm{P}$ circulation activities respectively. These results indicated that bacterial biomass, $\mathrm{N}$ circulation activity, $\mathrm{NH}_{4}^{+}$oxidation activity, $\mathrm{NO}_{2}^{-}$oxidation activity, and $\mathrm{P}$ circulation were the highest in organic farming orchards and the lowest in conventional orchards. Thus, apple orchard soils under organic farming methods showed increased bacterial biomass and enhanced $\mathrm{N}$ and $\mathrm{P}$ circulation activities.

\section{Discussion}

To assess the characteristics of soil conditions for apple cultivation under four 
farming methods, we investigated the chemical and biological properties of soils and fruits under four types of management systems: natural conditions, organic farming, hybrid farming, and conventional farming.

Kubo et al. (2017) [7] reported that the recommended carbon and nitrogen contents and $\mathrm{C} / \mathrm{N}$ ratio for orchard soils are $25,000 \mathrm{mg} \cdot \mathrm{kg}^{-1}$ or higher, 1500 $\mathrm{mg} \cdot \mathrm{kg}^{-1}$ or higher, and $10-25$, respectively. In this study, these recommended values were not reached in two orchards under natural farming systems nor in two orchards using hybrid farming methods (Figure 3). In the natural farming orchards, soils might have been deficient in TN because no fertilizer had been added for nearly 5 years. As for the hybrid farming orchards, the soils might have been deficient in TC or TN. Meanwhile, the conventional apple orchard soils closely matched the recommended values, indicating that the fertilizer applied in accordance with the guidelines of the prefectures and municipalities is appropriate. In turn, the TC and TN values in the organic orchards under study were also all within the recommended range, although very large variation among these orchards was observed.

This finding suggests that apple cultivation in these organic orchards depends on the experience and intuition of each farmer and that at present, its reproducibility is low. Therefore, it is necessary to assess the soil conditions in each orchard, as well as the components of compost and organic materials used. With this information, it should be possible to decide more accurately which nutrients are needed and how much organic fertilizer to apply. This will promote soil conditions in which microorganisms thrive, improving soil biodiversity and nutrient cycling. Overall, the effect should be a highly reproducible organic agriculture in harmony with the local environment.

The relationship between soil TC and soil bacterial biomass in orchard soils we have surveyed under the four farming management strategies is shown in Figure 4.

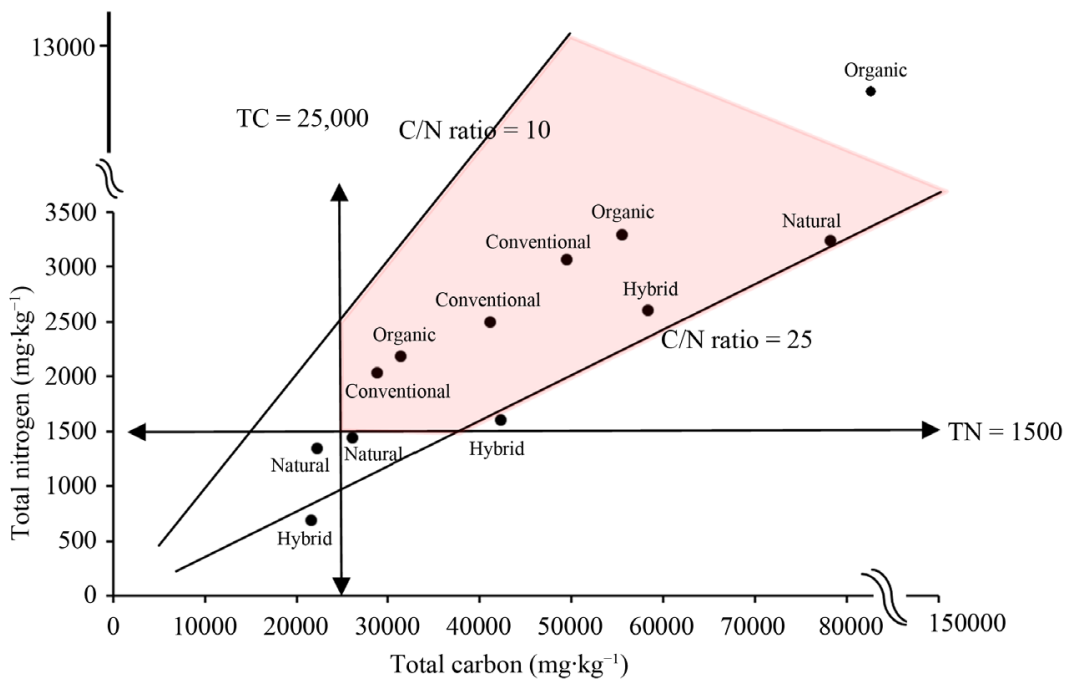

Figure 3. Correlation between total carbon and total nitrogen in 12 apple orchard soils (n $=12$ ). 


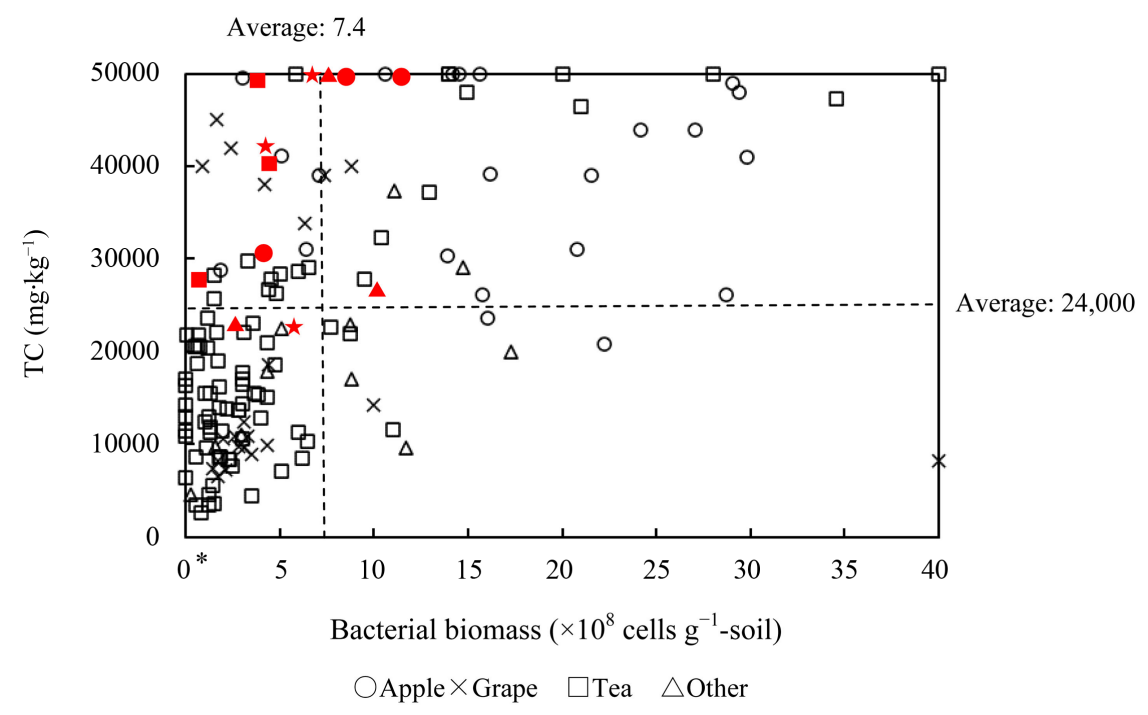

Figure 4. Relationship between soil total carbon and soil bacterial biomass using $(\boldsymbol{\Delta})$ natural, ( $)$ organic, $(\star)$ hybrid, and ( $)$ conventional farming methods.

The average TC in orchard soils was $24,000 \mathrm{mg} \cdot \mathrm{kg}^{-1}$ under our database, while the corresponding average bacterial biomass was $7.4 \times 10^{8}$ cell $\mathrm{g}^{-1}$. Organic farming soils showed the highest TC and the largest bacterial biomass, whereas the lowest values were recorded for conventional farming soils, implying that the soil bacterial biomass in conventionally farmed apple orchards decreased with the use of chemical fertilizers and synthetic pesticides.

This study indicated that the differences in apple sugar content, acidity, and sugar/acidity ratio between different orchard management systems were due to different soil conditions, and soil conditions under organic farming management system in apple cultivation increased microbial biomass while enhancing $\mathrm{N}$ and $\mathrm{P}$ cycle activity and high TC.

\section{Acknowledgements}

This work was supported by JSPS KAKENHI Grant Number JP19K15937.

\section{Conflicts of Interest}

The authors declare no conflicts of interest regarding the publication of this paper.

\section{References}

[1] McNeill, J., Barrie, F.R., Buck, W.R., Demoulin, V., Greuter, W., Hawksworth, D.L., Herendeen, P.S., Knapp, S., Marhold, K., Prado, J., Van Reine, P., Smith, G.F., Wiersema, J.H. and Turland, N.J. (2012) International Code of Nomenclature for Algae, Fungi, and Plants (Melbourne Code). The 8 th International Botanical Congress Melbourne, Australia, July 2011, 1-40.

[2] Forsline, P.L., Aldwinckle, H.S., Dickson, E.E., Luby, J.J. and Hokanson, S.C. (2003) Collection, Maintenance, Characterization, and Utilization of Wild Apples of Central Asia. In: Janick, J., Ed., Horticultural Reviews. Wild Apple and Fruit Trees of 
Central Asia, Vol. 29, John Wiley \& Sons, Inc., Hoboken, 1-62.

https://doi.org/10.1002/9780470650868.ch1

[3] Cornille, A., Gladieux, P., Smulders, M.J., Roldán-Ruiz, I., Laurens, F., Le Cam, B., Nersesyan, A., Clavel, J., Olonova, M., Feugey, L., Gabrielyan, I., Zhang, X.G. and Giraud, T. (2012) New Insight into the History of Domesticated Apple: Secondary Contribution of the European Wild Apple to the Genome of Cultivated Varieties. PLOS Genetics, 8, e1002703. https://doi.org/10.1371/journal.pgen.1002703

[4] Koike, H. (2006) NHK Hobby Horticulture 12 Months Cultivation Apples. NHK Publishing, Tokyo, 4-127.

[5] Ministry of Agriculture, Forestry and Fisheries (2019). https://www.maff.go.jp/j/tokei/kouhyou/sakumotu/sakkyou_kazyu/

[6] FAO (2014) FAOSTAT. http://faostat3.fao.org/home/E

[7] Kubo, M., Adhikari, D., Araki, S.K., Kubota, K., Shinozaki, A., Matsuda, F., Mitsukoshi, K., Mukai, M. and Watarai, H. (2017) Science of Soil Making. Seibundo Shinkosha Co., Ltd., Japan, 2-185.

[8] Reganold, J.P., Glover, J.D., Andrews, P.K. and Hinman, H.R. (2001) Sustainability of Three Apple Production Systems. Nature, 410, 926-930. https://doi.org/10.1038/35073574

[9] De Ponti, T., Rijk, B. and Van Ittersum, M.K. (2012) The Crop Yield Gap between Organic and Conventional Agriculture. Agricultural Systems, 108, 1-9. https://doi.org/10.1016/j.agsy.2011.12.004

[10] Dris, R. (2002) Influence of Orchard Management on Growth and Production of Fruits. In: Dris, T., Jain, S.M. and Khan, I.A., Eds., Environment and Crop Production, Science Publishers Inc., Enfield, NH, 1-3.

[11] Aggelopoulou, K.D., Wulfsohn, D., Fountas, S., Gemtos, T.A., Nanos, G.D. and Blackmore, S. (2010) Spatial Variation in Yield and Quality in a Small Apple Orchard. Precision Agriculture, 11, 538-556.

https://doi.org/10.1007/s11119-009-9146-9

[12] Fujisawa, M. and Kobayashi, K. (2013) Shifting from Apple to Peach Farming in Kazuno, Northern Japan: Perceptions of and Responses to Climatic and Non-Climatic Impacts. Regional Environmental Change, 13, 1211-1222.

https://doi.org/10.1007/s10113-013-0434-6

[13] Adhikari, D., Kai, T., Mukai, M., Araki, S.K. and Kubo, M. (2014) Proposal for a Soil Fertility Index (SOFIX) for Organic Agriculture and Construction of a SOFIX Database for Agricultural Fields. Current Topics in Biotechnology, 8, 81-91.

[14] Kai, T., Mukai, M., Araki, K.S., Adhikari, D. and Kubo, M. (2015) Physical and Biochemical Properties of Apple Orchard Soils of Different Productivities. Open Journal of Soil Science, 5, 149-156. https://doi.org/10.4236/ojss.2015.57015

[15] Kai, T., Mukai, M., Araki, K. S., Adhikari, D. and Kubo, M. (2016) Analysis of Chemical and biological Soil Properties in Organically and Conventionally Fertilized Apple Orchards. Journal of Agricultural Chemistry and Environment, 5, 92-99. https://doi.org/10.4236/jacen.2016.52010

[16] Nagano Agricultural Administration Department (2018) The Guide of Environment-Friendly Agricultural Technology.

https://www.pref.nagano.lg.jp/nogi/sangyo/nogyo/hiryo/documents/naganoken.pdf

[17] Nicholas, D.J.D. and Nason, A. (1957) Determination of Nitrate and Nitrite. $\mathrm{Me}$ thods in Enzymology, 3, 981-984. https://doi.org/10.1016/S0076-6879(57)03489-8

[18] Murphy, J. and Riley, J. P. (1962) A Modified Single Solution Method for the De- 
termination of Phosphate in Natural Waters. Analytica Chimica Acta, 27, 31-36. https://doi.org/10.1016/S0003-2670(00)88444-5

[19] Adhikari, D., Kai, T., Mukai, M., Araki, S.K. and Kubo, M. (2014) Proposal for a New Soil Fertility Index (SOFIX) for Organic Agriculture and Construction of a SOFIX Database for Agricultural Fields. Current Topics in Biotechnology, 8, 81-91.

[20] Aoshima, H., Kimura, A., Shibutani, A., Okada, C., Matsumiya, Y. and Kubo, M. (2006) Evaluation of Soil Bacterial Biomass Using Environmental DNA Extracted by Slow-Stirring Method. Applied Microbiology and Biotechnology, 71, 875-880. https://doi.org/10.1007/s00253-005-0245-x

[21] Matsuno, T., Horii, S., Sato, T., Matsumiya, Y. and Kubo, M. (2013) Analysis of Nitrification in Agricultural Soil and Improvement of Nitrogen Circulation with Autotrophic Ammonia-Oxidizing Bacteria. Applied Biochemistry and Biotechnology, 169, 795-809. https://doi.org/10.1007/s12010-012-0029-6

[22] Horii, S., Matsuno, T., Tagomori, J., Mukai, M., Adhikari, D. and Kubo, M. (2013) Isolation and Identification of Phytate Degrading Bacteria and Their Contribution to Phytate Mineralization in Soil. Journal of General and Applied Microbiology, 59, 353-360. https://doi.org/10.2323/jgam.59.353

[23] Ishiyama, M. (1990) Trends in Apple Flavor and Objectives in Breeding. Tohoku Agric. Res. Extra Issue, 3, 61-70.

http://www.naro.affrc.go.jp/org/tarc/to-noken/DB/DATA/e03/e03-061.pdf\#search= \%E3\%83\%AA\%E3\%83\%B3\%E3\%82\%B4\%E3\%81\%AE\%E5\%97\%9C\%E5\%A5\%BD \%Е3\%81\%A8\%E5\%93\%81\%E7\%A8\%AE\%E8\%82\%B2\%E6\%88\%90\%E3\%81\%AE\% E6\%96\%B9\%E5\%90\%91' 